\title{
The Welfare State and the Good Society
}

\author{
James Cox
}

1

THE growth in spending on the welfare state has been one of the great structural changes in Australia, New Zealand and similar countries during recent decades. Between 1962 and 1995, government spending on health, education, social security and housing rose in Australia from 13 per cent of GDP to 21 per cent; transfers from governments to persons rose from 6 per cent of GDP to 11 per cent.

Critics of the growth of government have stressed its possible implications for the incentives to work and to save and for family stability. Some commentators have detected a decline in the sense of personal responsibility, as manifested in increasing crime rates, avoidance of work by the able-bodied, and unmarried motherhood. Supporters of an even larger role of government, in contrast, argue that government programs are an important and irreplaceable part of the social fabric, and that government policies of recent years, such as privatisation, contracting out and the stricter targeting of welfare, have added to our social problems by damaging that fabric.

This article attempts to evaluate these alternative views of the social effects of the welfare state. First, it considers the arguments recently advanced by David Green and Eva Cox, which are representative of the two positions summarised above. The available statistical evidence is then assembled and discussed, and some implications are drawn. Although the evidence is suggestive rather than conclusive, the views expressed go beyond mere opinion. The relevance, if any, of this analysis for government policy is then discussed. The article concludes by reflecting on some of the broader issues that have been raised.

\section{Conflicting Views of Civil Society}

David Green. In From Welfare State to Civil Society: Towards Welfare that Works in New Zealand (1996), David Green argues that state paternalism has damaged New Zealand society. Since the late 1970 s, the welfare state has been increasingly afflicted by a number of problems, including: rising expenditure on the welfare state (despite efforts by governments to control it); poor service quality and absence of choice in welfare services; rising taxes and increased government debt; and reduced incentives to work arising from the combined effects of the social security and tax systems. More recently, New Zealanders have become concerned about

James Cox is a member of the Independent Pricing and Regulatory Tribunal of New South Wales. 
rising crime, diminished work effort, family breakdown and the lack of economic progress by the Maori community. In contrast with the 19th century, 'very few people take personal pride in assuming responsibility for the direct resolution of problems' (p. 104). The voluntary associations that previously were so important a part of Australian and New Zealand society have been crowded out by government activity. These days, activism is likely to lead to demands that government - which means other people - should take action. Activism 'is doubly pernicious because, on the one hand, it denies personal responsibility and, on the other, it dresses up political demands as altruism when they are no such thing' (p. 105).

These problems have arisen largely because the welfare state has weakened people's sense of responsibility for themselves and for others. Those down on their luck are considered to be not independent moral agents but victims of circumstance. Moreover, the growth of the welfare state "has diminished opportunities for people to be of service to each other, impairing the quality of life and encouraging us to look outwards to "the authorities", instead of inwards to our own strengths and skills, for solutions to shared problems' (p. vii). The erosion of the sense of personal responsibility is especially serious because it weakens the qualities on which a free society depends. To resist the concentration of power in political hands is to advocate the dispersal of decision making to people assumed to be capable of bearing responsibility, respecting others, and making intelligent decisions' (p. 28). 'Because our eyes have been fixed on the economy', Green argues, 'we have not been alert to mistaken doctrines which have caused family breakdown and turned voluntary associations - once sources of that strength of character which insulates nations from tyranny - directly or indirectly into instruments of the state' (p. 30).

Green's recommendations for limiting the role of government and increasing the scope for self-reliance and what he calls 'community without politics' are inspired by a view of the good society in which human beings achieve fulfilment by assuming personal responsibility for self-improvement and by making the world a better place for others. The community is united not under central leadership but in accepting the conditions which allow us all to exercise responsibility. It is the job of government to maintain the conditions under which all this can take place.

Eva Cox. In A Truly Civil Society (1995), Eva Cox is concerned about 'the loss of social cohesion and loss of faith in the possibilities of solving social problems' in our societies (p. 4). More people live alone than ever before and must make deliberate efforts to be sociable. The increased competition that has been encouraged by government policy in recent years threatens to destroy society by limiting the scope for cooperation. Most seriously, there has been a loss of faith in government. 'If part of our sense of well-being is our faith in governments, the denigration of public services by governments reduces our sense of comfort and trust' (p. 10). The reduction in public services and the reform of some utilities have resulted in a sense of loss, an unravelling and tearing of the social fabric, 'suspicion and isolation rather than a sense of belonging' (p. 73). In particular, because child care is not universally provided, we are in danger of producing children who lack the skills re- 
quired for good trust relationships. Although pressure for expanded governmentsubsidised child care has been successful, work-related child-care needs have been over-emphasised. 'Few parents on their own have the capacity to train their children in sociability' (p. 32); hence the need for universal government-provided child care.

Because families are 'small fragile units', a strong state is needed to integrate society. Moreover, the state is 'the best hope for positive change' (p. 47). Democratic, centralised power gives outsider groups 'the best assurance that their needs will not be ignored'. Above all, Cox celebrates the life of the political activist: a life of discussion, openness to ideas, acceptance of outsiders and political engagement (though she pays little attention to how the beneficiaries of government programs, as opposed to those who lobby on their behalf, can participate in this life). Cox wants changes that involve 'the productive interplay of state and community, because it is in this interplay that we can create a truly civil society' (p. 46). So whereas David Green argues that government programs limit the scope for self-improvement and private effort to help others, therefore weakening society, Eva Cox insists that the relationship between government programs and community effort is essentially complementary. Because institutions such as the family and community are so weak, only government can stand between the individual and the blind forces of the market. Policy changes which weaken government programs therefore also weaken society.

In trying to test these conflicting views against the evidence ${ }^{1}$ and to determine whether the expansion in government welfare has tended to strengthen or weaken private effort, I will examine the following questions:

- Has the growth in welfare state spending in recent years been well-directed to areas of emerging need or has it reflected other, perhaps political, priorities?

- Has the growth in welfare spending and its funding on balance improved or worsened the situation of families with children?

- Has the expanded provision of subsidised child care by governments affected the care that families provide for their own children?

- Has the provision of care for the aged and the disabled by family or other informal networks diminished to such an extent that expanded government provision is unavoidable?

\footnotetext{
${ }^{1}$ The available evidence is patchy and unsatisfactory in many respects. The analysis presented here is based on published statistical tables; a more informative analysis would be based on unit record data from the household expenditure surveys. Because the subject matter of this paper is so important and so little discussed, I believe that the exploratory survey made in this paper is justified. It is to be hoped that better data and more sophisticated analysis will soon be made available.
} 
- Has increased government involvement in welfare coincided with increased or reduced voluntary effort?

\section{The Growth in Government Welfare Spending and its Impact on Households}

Figure 1 shows total spending since $1961 / 62$ by all Australian governments on education, health, social security and welfare, and housing and community activities, expressed as a share of GDP. Figure 1 also shows the growth in personal benefit payments. The share of the population receiving one of the four main social security benefits (age pensions, unemployment benefits, disability pensions and sole parent pensions) increased from 12.5 per cent of the population aged 16 years and over in 1973 to 23 per cent in 1993 (ABS, 1994:147).

\section{Figure 1}

\section{Government social welfare expenditure and personal benefit payments in Australia as percentages of GDP, 1961/62-1995/96}

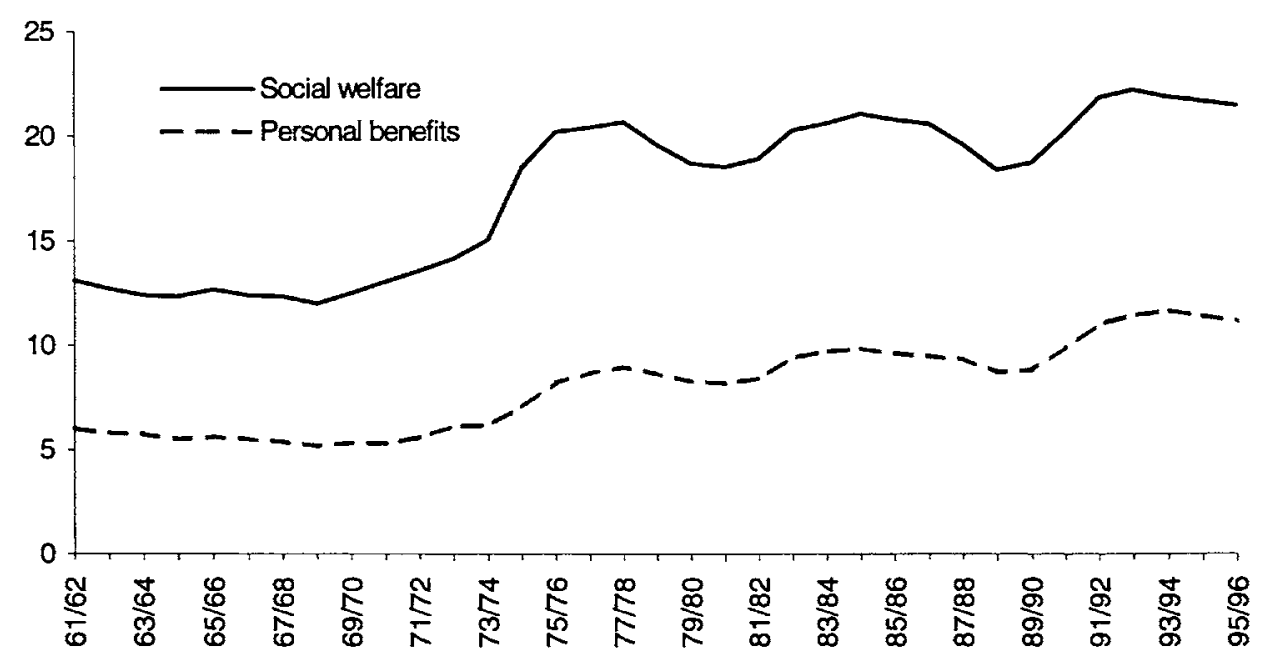

Source: ABS (1995).

The share of government revenue in GDP has also grown since the mid-1970s. During the period 1988/89-1993/94, revenues fell as a share of GDP from 36.8 per cent to 34 per cent while total outlays increased from 36.6 per cent to 40.4 per cent (see Cox, 1994, for further discussion). This is of some importance for the subsequent analysis.

The ABS household expenditure surveys provide the best data for understanding how the growth in government spending and taxation has affected the various kinds of households. The Australian Statistician has, since the 1984 survey, pub- 
lished estimates, based on these surveys, of the effect of government benefits and taxes on household incomes. Only the more recent developments in the welfare state and its financing can be studied using these data, which therefore do not cover the great upsurge in spending which occurred during the mid-1970s.

Although these comprehensive data are available for only a short period, other, more limited, data suggest that the processes described here have been operating over a longer period. For example, my findings that during recent years the welfare state has increasingly benefited older people and penalised two-parent families with children are corroborated by David Thomson (1991), who shows that the welfare state in New Zealand has provided greatest advantage to increasingly older age groups during the period since World War II, and by EPAC (1988, Appendix 3), which shows that average effective tax rates rose far more quickly over the period 1949/50-1988/87 for a taxpayer with a spouse and children than for a single taxpayer. I show below that these trends have continued in the most recent years, and have affected a wider range of families.

Most attention is usually paid to the effects of government spending and taxation on the distribution of income. However, households in the lowest deciles of the income distribution tend to be smaller (and older) than average; and their needs may also be relatively small. For example, each household in the lowest quintile of the income distribution has 1.6 persons on average but each household in the highest quintile has 3.4 persons on average (ABS, 1996a:12). Income, therefore, may not be closely related to need. Moreover, some households may understate income to qualify for benefits or minimise tax and may report these understated incomes to the ABS.

Although the relationships between benefits, taxation and income are obviously important, it may be equally valid to examine the financial relationships between households of differing ages and composition on the the one hand and government on the other. This is particularly true because I wish to examine the financial situation of average families of different types, and not just those with low incomes. I have therefore chosen to look at the financial situations of households of differing age and composition. (Some methodological and statistical issues in presenting and interpreting the data are explained in the Appendix.)

\section{Distribution among Age Groups}

Table 1 reveals the high share of taxation paid by households with a reference person aged between 25 and 54 years. This group, which contained 61 per cent of reference persons in 1993/94, received 56 per cent of benefits but paid 79 per cent of taxes. By contrast, the 32 per cent of reference persons who were aged 55 or more years received 39 per cent of benefits and paid 16 per cent of taxes.

Despite the aging of the population, there was not a large increase between 1984 and 1993/94 in the share of households with reference persons aged 65 years and over. The numbers aged $45-54$ years increased as a share of the population but those aged 25-34 years and 55-64 years decreased as a share of the population, in the latter case reflecting the low number of births during the 1930s. The increase in 
government welfare spending between 1984 and 1993/94 was therefore not appreciably due to demographic factors.

Table 1

Percentage shares of government benefits and taxes by age of household reference person: Australia 1984-1993/94

Under 25 years

Benefit share $1993 / 94$ $1988 / 89$ 1984

Taxation share 4.54

3.57

4.91

Share of total

5.27

5.19

6.50

households

6.39

5.63

6.83

25 - 34 years

Benefit share

Taxation share

16.65

14.34

17.53

22.84

24.73

25.64

Share of total

20.22

21.55

22.44

households

$35-44$ vears

Benefit share

Taxation share

23.66

26.41

23.89

Share of total

28.72

30.55

26.29

households

21.88

23.65

20.82

$45-54$ years

Benefit Share

16.01

15.15

15.03

Taxation Share

27.08

21.50

21.31

Share of total

19.34

16.00

15.01

households

$55-64$ vears

Benefit Share

11.43

12.52

14.31

Taxation Share

10.18

11.99

14.02

Share of total

12.75

14.56

15.95

households

65 years and over

Benefit Share

27.71

28.01

24.32

Taxation Share

5.90

6.04

6.24

Share of total

19.42

18.61

18.96

households

Note: Entries may not sum to 100 per cent, due to rounding.

Sources: ABS (1987, 1992, 1996a); author's calculations. 
Households in which the reference person was aged 35-54 years were treated increasingly less favourably by the welfare state during 1984-1993/94, mainly because their shares of taxation increased rapidly over the decade. By contrast, households where the reference person was aged under 25 years or over 65 years received increasingly favourable treatment from the welfare state. For example, the share of benefits received by households over 65 years increased from 24.3 per cent to 27.7 per cent during 1984-1993/94. Those households aged 55-64 years received slightly more favourable treatment over the period, largely because they paid a falling share of taxation. Households where the reference person is aged 25-34 years received less favourable treatment by government in 1988/89 than in 1983/84, but more favourable treatment in 1993/94 than in either of the two earlier years. This apparent change may be due at least in part to the revised treatment of expenditure on child care (see Appendix).

The period 1984-1993/94 was in many ways a difficult one for persons of working age. Unemployment was relatively high on average, and the inequality of earnings increased. The fact that the welfare state treated those aged over 55 years more favourably and those aged under 55 on average less favourably over this period may suggest that, rather than responding to changing needs, the welfare state developed to a considerable extent according to its own, political, logic.

\section{Distribution by Type of Households}

Some information on the changing relationship between households of various types and the welfare state is presented in Table 2.

Significant changes have occurred in the proportions of the various types of household in the total. In particular, the proportion of households that are couples with only dependent children fell significantly, from 29.7 per cent of all households to 23.7 per cent during 1984-1993/94, mainly after 1988/89. The size of this reduction is surprising, although census data suggest that the share of households which are couples with dependants has been falling at least since 1976 (ABS, 1994:36). Conversely, younger couples without children, sole parents and lone persons have all increased as a proportion of total households. The share of multiple unit households has remained roughly constant.

Bearing these changes in mind, a number of findings are evident from Table 2. First, younger couples without children received increasingly less favourable treatment from the welfare state, largely because their share of benefits did not increase in line with the increased share of this group in total households. By contrast, the share of benefits going to older couples increased sharply.

Second, couples with only dependent children receive a greater than proportionate share of government benefits and pay an even greater share of taxes. During 1984-1993/94 the tax system became less favourable to families with dependent children (particularly during 1984-1988/89; the reduction in revenue as a share of GDP during 1988/89-1993/94 was of particular benefit to families with children). The benefits system treated families less generously in 1988/89 than in 1984, but this trend was apparently reversed during 1988/89-1993/94, possibly reflecting the 
revised allocation of government expenditure on childcare to households by the ABS (see Appendix).

\section{Table 2}

\section{Percentage shares of government benefits and taxes by household composition: Australia 1984-1993/94}

\begin{tabular}{|c|c|c|c|}
\hline \multicolumn{4}{|c|}{ Younger couples ${ }^{a}$ without children } \\
\hline Benefit share & 4.15 & 2.83 & 3.52 \\
\hline Taxation share & 17.67 & 13.02 & 14.18 \\
\hline Share of total households & 12.76 & 9.33 & 9.69 \\
\hline \multicolumn{4}{|c|}{ Older couples ${ }^{b}$ without children } \\
\hline Benefit share & 16.79 & 17.89 & 15.78 \\
\hline Taxation share & 6.63 & 7.51 & 7.30 \\
\hline Share of total households & 13.09 & 13.83 & 14.22 \\
\hline \multicolumn{4}{|c|}{ Couples with dependent children } \\
\hline \multicolumn{4}{|c|}{ only } \\
\hline Benefit share & 28.17 & 30.79 & 32.30 \\
\hline Taxation share & 30.97 & 36.72 & 35.37 \\
\hline Share of total households & 23.68 & 28.36 & 29.68 \\
\hline \multicolumn{4}{|l|}{ Sole parents } \\
\hline Benefit share & 9.06 & 7.57 & 5.82 \\
\hline Taxation share & 1.84 & 1.54 & 1.29 \\
\hline Share of total households & 5.11 & 4.55 & 3.62 \\
\hline \multicolumn{4}{|l|}{ Younger lone persons $^{a}$} \\
\hline Benefit share & 3.04 & 1.95 & 2.20 \\
\hline Taxation share & 8.05 & 7.16 & 6.54 \\
\hline Share of total households & 9.95 & 8.86 & 7.67 \\
\hline \multicolumn{4}{|l|}{ Older lone persons ${ }^{b}$} \\
\hline$\overline{\text { Benefit share }}$ & 11.86 & 10.87 & 10.06 \\
\hline Taxation share & 2.12 & 2.04 & 2.53 \\
\hline Share of total households & 11.85 & 11.45 & 11.41 \\
\hline \multicolumn{4}{|c|}{ Multiple income unit households ${ }^{c}$} \\
\hline Benefit share & 26.92 & 28.10 & 30.32 \\
\hline Taxation share & 32.71 & 32.01 & 32.79 \\
\hline Share of total households & 23.57 & 23.61 & 23.71 \\
\hline \multicolumn{4}{|c|}{$\begin{array}{l}\text { Notes: Entries may not sum to } 100 \text { per cent, due to rounding. } \\
\text { ander } 55 \text { years. } 55 \text { years and over. "households with non-dependent children or those } \\
\text { which include several adults, but not only a couple. Non-dependent children are children } \\
\text { aged over } 15 \text { years but not full-time students aged } 15-20 \text { years. }\end{array}$} \\
\hline
\end{tabular}

Sources: ABS (1987, 1992, 1996a); author's calculations. 
Third, sole parents received increasingly generous treatment from the welfare state, largely due to their increasing share of benefits.

Fourth, lone persons were also treated increasingly generously, especially older lone persons who received a larger share of benefits and paid a lower share of taxes during 1984-1993/94. The share of taxation paid by younger lone persons did not increase as rapidly as their share in the total population.

Fifth, multiple income unit households received increasingly adverse treatment, due to their sharply reduced share of government benefits. Many of these households include dependent children, or non-dependent children who rely on their parents to some extent, because of factors such as unemployment.

Sixth, younger couples, younger lone persons, couples with only dependent children and multiple income unit households pay shares of taxes that are greater than their shares of benefits. Couples with only dependent children, multiple income unit households and younger couples also pay shares of taxes which are disproportionately high in relation to their numbers. The reverse of both statements is true for sole parents, older couples and lone persons.

In summary, the welfare state redistributes from younger couples, couples with children and multiple income unit households to sole parents and older couples and older lone persons. On the whole, these trends tended to intensify during 1984-1993/94, with the exception that the reduction in government revenue from 36.8 per cent of GDP in 1988/89 to 34 per cent of GDP in 1993/94 seems especially to have benefited couples with dependent children only.

It is interesting that the proportion of households that are single persons and sole parents increased rapidly over this period but that the proportion of families with dependent children decreased. It is hard to believe that changes to the taxation and social security arrangements are not part of the explanation. As noted, single persons and sole parents received increasingly favourable treatment by the welfare state but families with children received increasingly less favourable treatment. Social policy changes of recent decades have made it increasingly easy for people to live apart from families: indeed, that was part of their rationale.

It is true that changes in the shares of taxation paid by various groups largely reflect changes in the shares of private income they earn. But private income is at least partially under the control of the persons who earn it; they decide the extent and nature of their participation in market activity. The extent to which people arrange their financial affairs to receive a low income will depend on the need for income to support dependents and the availability and generosity of welfare siate benefits. In this respect, it is significant that the distribution of private income became increasingly concentrated during 1984-1993/94. Younger couples, couples with only dependent children and multiple unit householders constituted 63 per cent of households in 1984 but earned 83 per cent of private income; in 1993/94 the corresponding figures were 60 per cent and 83 per cent respectively (see Table 2 and references there). Such changes should be taken into account in evaluating the equity impact of the welfare state. 
The moral dilemmas facing policy-makers have been sharpened by recent evidence suggesting that the two-parent family is generally better for children than the one-parent family. For example, Alan Tapper (1996) reports, based on a Western Australian survey of child health, that children in sole-parent families are more likely to suffer from mental health problems than children from intact families (the risk from children in blended families is in between these two). Barry Maley (1996) reports, based on a study of New South Wales crime statistics, that there is a relationship between family status and crime. Angus and Hall (1996) claim that data from the Australian Institute of Health and Welfare indicate that children from sole-parent families are eight times, and children in blended families 14 times, as likely to suffer abuse and neglect as children living with their natural parents. There are many possible explanations for this result; perhaps abuse in sole-parent families is more likely to be reported. And the interests of children need to be considered by policy-makers irrespective of the circumstances of their parents. Nevertheless, whatever the role of such factors, the wider social consequences of the existing subsidies are surely a matter of great concern.

\section{Care of Children and of Persons with a Disability}

The care of children and of persons with a disability is among the most important and difficult tasks that a society must undertake. Information about the extent to which it is carried out within families or, more broadly, on a voluntary basis within the wider society would give an indication of the strength of civil society in Australia. As well, information about the effect of expanded government child-care subsidies in recent years would help us understand the relationship between government and private effort in this area.

The ABS (1994:47-9) reports that the number of government-subsidised child care places increased from 59,000 in 1984 to 211,000 in 1993. A distinction is drawn between formal care (regulated care away from the child's home) and informal care (non-regulated care - other than by the child's parents - either in the child's home or elsewhere). According to the ABS (1994:47), 'most care of children other than by parents is provided on an informal basis, mainly by other family members'. 2 The proportion of children who are looked after only by their parents decreased from 61.5 per cent in 1984 to 51.2 per cent in 1993, most of this decline occurring during 1984-87. The use of child care has declined overall since 1990, perhaps reflecting a stabilisation in the labour-force participation rate of married women.

The proportion of children receiving formal child care only has increased from 8.7 per cent in 1984 to 11 per cent in 1993; most of this increase occurred during 1990-93, when the use of child care in total was falling. As a consequence, the share of children receiving informal care only has fallen from 33.9 per cent in 1990 to

\footnotetext{
${ }^{2}$ In 1993, 51.2 per cent of children aged under 11 years of age were cared for by their parents. Eleven per cent received formal care only, 29.4 per cent informal care (mainly from grandparents or other female relations) and 8.3 per cent a combination of formal and informal care.
} 
29.4 per cent in 1993. The increased provision of regulated child care in recent years seems, therefore, to have resulted not in increased work by mothers but in reduced care by grandmothers or other relations. Something may have been lost in terms of the generations providing assistance one to another.

ABS surveys undertaken in 1988 and 1993 of persons with a disability and of their carers (ABS, 1990, 1993) found that most help is provided informally by spouses, other relations or friends and neighbours. For example, in 1993 over 90 per cent of persons who need help for self care, mobility, verbal communication, personal affairs and transport received it informally; over 75 per cent of those requiring help for meal preparation, home maintenance and home help received it informally; almost twice as many people received home care and home-help services from unrelated friends and neighbours as from formal services; and over 54 per cent of persons who receive help for health care received it informally. The most important providers of formal help were relatively unsubsidised: 'privately arranged help/commercially provided service' and 'chiropodist/podiatrist'. Only 30 per cent of persons who received formal help received it from 'home care/home help/council handypersons'.

Most needs for assistance are met: for most activities, unmet need amounts to less than 10 per cent of the total. Exceptions include home care, where up to 15 per cent of need for assistance was reported to be unmet.

According to the ABS (1996c:209), 60 per cent of persons with a handicap who were living in households and who received assistance received informal assistance only. Eight per cent received formal assistance only and 32 per cent received both formal and informal assistance. Only 6 per cent of persons with a handicap live in establishments such as hospitals or nursing homes.

Comparison between the 1988 and the 1993 surveys is not easy: there are differences, for example, in the population covered. Nevertheless, the numbers of people with a disability who received formal help seems to have increased between the two surveys. Much of the increase was for privately arranged help or podiatrists; the number receiving home-care services showed little change. Governmentsubsidised formal care for persons with a disability does not appear to have expanded greatly during 1988-93; consequently, any 'crowding out' of private effort by government-subsidised services would also have been small. Even so, there are some indications that private, informal care for persons with a disability diminished during that period (though it should be noted that significantly more information was required of carers in 1993 than in 1988, which may have influenced whether people identified themselves as carers). For example, the number of daughters providing home help and sons assisting with home maintenance fell. These changes no doubt reflect broader social and economic trends, including greater labour-force participation by women and perhaps a greater tendency for persons with a disability to live apart from their families. On the other hand, the numbers of people receiving assistance from unrelated friends and neighbours did not fall between the two years. 


\section{Participation in Voluntary Community Activities}

As noted by Eva Cox, writers such as David Putnam (1993) have argued that a good indicator of the health of civil society is the level of participation in voluntary activities which both have a clear objective and a fairly egalitarian structure. This is because participation in such activities both reflects and develops those skills and attributes, like trust and the habit of cooperation, which are required if the institutions of either politics or the market are to function well.

By these standards, Australian society is healthy. According to the New South Wales Department of Fair Trading, 19,300 non-profit associations were registered under the Associations Incorporation Act in June 1994 (Department of Consumer Affairs, 1994). This represents one association for every 313 persons in New South Wales in that year. The number of incorporated associations is growing by about 2,000 a year and compares more than favourably with Putnam's figures, obtained from a census of associations, for the most civic regions of Italy such as TrentinoAlto Adige (Putnam, 1993:91-2).

The ABS has also undertaken some surveys of participation in voluntary work in Australia. The most recent survey (ABS, 1996b), shows that 19 per cent of the population aged 15 years and over provided some form of voluntary work through an organisation or group in 1995 . Women were more likely to volunteer than men, and those with dependants were more likely to volunteer than those without. People aged 35-44 years are more likely to volunteer than younger or older persons. Thus, participation in voluntary work in Australia does not follow the pattern, observed by Putnam (1996), of high membership in associations during the later years of life, which Putnam considers in indicative of the high level of civic engagement among older Americans.

Participation in voluntary work may be waning. Whereas an ABS (1986) survey in New South Wales in October 1986 found that 18.5 per cent of males and 29.3 per cent of females provided voluntary service through an organisation in the twelve months prior to the interview, the corresponding figures from the 1995 survey were 13.1 per cent and 17.7 per cent, respectively (though it should be noted that the ABS did not release the final report of the 1986 survey, presumably because of concerns about data quality).

\section{How Strong Is Australia's Civil Society?}

The foregoing analysis permits us to be fairly optimistic about the state of civil society. Well-functioning families are able to protect their children from abuse, mental health problems, and engaging in criminal behaviour. Most care of children (other than by parents) is undertaken by female relations. Most persons with a disability who receive help receive it from a spouse, relation, friend or neighbour. Australia has many voluntary organisations. And a large proportion of the population undertakes voluntary work. Yet the number of sole-parent families has increased in recent years, despite the many disadvantages such families suffer. As well, the num- 
ber of persons undertaking voluntary work and providing informal help to persons with disabilities seems to have fallen.

The expansion of the welfare state in recent years seems to have weakened the institutions of civil society. More people now rcly on government as a principal source of income. More people now live alone; redistribution within households is less important than it used to be. The growth in government-regulated child care has reduced the amount that is privately provided. The growth in the welfare state has tended to benefit the old at the expense of the young and the middle-aged. Redistribution has increasingly been from households with children and younger couples to single persons and the self-employed. These changes do not seem obviously to be justified by changes in the relative needs of the various groups.

It is true that some government programs, such as payments to working families with children or to carers of the disabled, may support rather than undermine the institutions of civil society; but, as we have seen, the general development of the welfare state in recent years has tended to disadvantage families with children. It is also true that the growth of the welfare state may simply reflect broader changes which in themselves have tended to weaken civil society. These include a greater desire for individual autonomy in an increasingly prosperous society. Many people may, because of the opportunity this provides them to pursue their own projects, prefer an extensive role for government in caring for the aged and the disabled, even at the expense of higher taxes and their consequences, rather than to provide such care themselves. In this connection, it is sometimes said that families are less able to care than in the past because so many adults are working. The irony here is that so many the new jobs in recent years which have been financed through increased taxation involve caring for other people's children and parents. Australia seems to have gone some small way towards the situation in Sweden noted by Rosen (1996:734-5):

In Sweden a large fraction of women take care of the children of women who work in the public sector to care for the parents of the women who are looking after their children. If Swedish women take care of each other's parents in exchange for taking care of each other's children, how much additional real output comes of it? In order for the state to provide services socially that otherwise would be privately produced in the family or the private sector, many ordinary, inherently personal activities must be reckoned in explicit monetary terms, tax revenues must be raised to finance them, and complex rules and conditions must be imposed to limit undesirable side effects.

Although such policies have been successful in increasing fertility and the economic independence of women, there are hidden efficiency and social losses resulting from the substitution of government-provided services for what otherwise would have been produced or purchased in other, more decentralised, ways. Moreover, the adverse effects of government welfare or private welfare help explain why the 
increase in government social spending since about 1960 has provided disappointing results in many countries.

\section{Policy Issues}

This analysis suggests that David Green's view of the welfare state is closer to the truth than Eva Cox's. There is a good deal of strength in the institutions of civil society in Australia; but expanded government effort displaces private effort, partly by reducing the need for private effort directed towards similar ends, and partly (through taxation and regulation) by reducing the capacity of society to pursue the ends it may consider desirable.

What are the implications for public policy? It should be remembered that debates about the future of the welfare state do not simply reflect differences in values, but are based at least in part on differing views about how society operates. The modern welfare state is little more than 50 years old; but we are gradually learning more about the connections between government and private effort. This, in turn, may eventually result in greater agreement about which policies are desirable. The World Bank (1994) report Averting the Old Age Crisis, which advocates a combination of government and private effort to provide income in retirement, is a good example of this process.

Meanwhile, governments should be cautious about further expansion of welfare programs. For example, the financing of expanded government programs through increased taxation is particularly likely to disadvantage younger people and families with children. A careful assessment of the distributional consequences should proceed any such expansion.

The most difficult issue, however, is the likely consequences of government withdrawal from certain areas of welfare state activity. Some writers, such as David Green, argue that self-help or alternative methods of redistribution would develop easily if government reduced the scale of certain of its activities. As noted, a great deal of private welfare activity already occurs in Australia. A core of private activity thus exists that might well be able to expand if the need arose. Even so, it is hard to assess to what extent, and how quickly, private effort would expand following a reduction in government effort. Even governments that believe in principle that certain activities are better undertaken by the private sector will be understandably cautious about reducing their social programs. They may prefer to reduce spending on the better-off, who can be expected to make alternative arrangements easily, than on the less well-off, who are more likely to be dependent on assistance from others. They may also prefer to reduce their effort in areas where well-developed private alternatives already exist.

Whatever the case, significant external pressures will force governments to reconsider their social policies. These include the need to keep government expenditure (and especially spending on benefits to individuals) under strict control, in order both to reduce government dissaving and, in an increasingly competitive world,

\footnotetext{
${ }^{3}$ See Tanzi and Schuknecht (1995) for further discussion.
} 
to permit reductions in tax rates. A good deal of cautious experimentation with alternative ways to meet society's social objectives is, therefore, likely to occur. Indeed, this process has already begun in Australia under both Labor and LiberalNational Coalition governments. There are, ironically, some dangers in caution; in particular, the desire to prescribe acceptable and safe alternatives to government provision can stifle the forces of innovation and competition - as is evident, for example, in the present debate about health insurance.

In considering withdrawal from certain welfare state activities, governments have to balance two sets of risks. The first is the risk of hardship to certain persons if government activity is reduced. This risk is often immediate and urgent. The second is the risk of progressively weakening civil society if government programs are maintained. This risk is longer-term and falls on unknown persons. It is hardly surprising that, until recently, governments have been more concerned about the first risk than the second. Even so, the emphasis is changing. The tension between the desire to reduce dependency on government and the distributional consequences of so doing is likely to continue to be an important issues for Australia, New Zealand and similar countries. But there are likely to be substantial rewards for countries that can manage these tensions well.

\section{Final Thoughts}

All of this has, of course, been said before. Scepticism about the effects of the welfare state arose early in its life. An important early criticism was provided by Bertrand de Jouvenal in 1949. As summarised by John Gray (1990:xiii-iv), the relevant part of de Jouvenal's argument is as follows:

Redistributionist policy is condemned by de Jouvenal ... for undermining the sense of personal responsibility. It does this by transferring authority for crucial life-decisions from the individuals who make them to the state. By catering for all the basic needs of the individual, the state leaves him with authority only in the sphere of how to spend his pocket money. Again, the effect of redistributionist policy is to disadvantage the family as against such legal fictions as the corporation - principally by conferring upon business immunities denied to families. The regime of high taxation inseparable from the redistributionist state has the further undesirable consequences of diminishing the sphere of free services in which people engage in convivial relationships without the expectation of payment - and thereby corroding the culture of civility that sustains liberal civilisation.

For de Jouvenal, however, the most profound result of redistributionist policy is the impetus it gives to the baleful process of centralisation. If the state confiscates high incomes and imposes penal rates of taxation on savings and investment, the state must take over the savings and investment activities that private individuals are no longer able to undertake. If, because of the confiscation of higher incomes, there are important social and cultural activities that can no longer be sustained privately, such as provision 
for high culture and the arts, then once again the state must assume responsibility for such activities through a program of subsidy. Inevitably, that state comes to exercise an ever-increasing degree of control over them. The consequence of a redistributionist policy, accordingly, is the curtailment of private initiative in many spheres of social life, the destruction of the man of independent means, and the weakening of civil society.

Many of our present anxieties - about the weakening of the sense of personal responsibility, the weakening of family ties, the weakening of civil society, low rates of household savings and government involvement with high culture and the arts would therefore be unsurprising to de Jouvenal. But it was reasonable, when he was writing in the late $1940 \mathrm{~s}$, to expect that the response in terms of reduced private effort to increased government provision of social services was less than it has turned out to be. And, given a desire to compensate for, and prevent a recurrence of, the disasters of the first half of the 20 th century, people of good will had every reason to take an optimistic view about the consequences of government provision. It is not longer possible to take so innocent a view. Reconstructing welfare states in the light of this new and sobering knowledge is a considerable task for policy-makers at the end of the 20 th century.

\section{Appendix}

\section{Statistical Issues in Presenting Household Expenditure Survey Data}

The surveys asked each household how much it paid in direct taxes and how much it received in social security benefits. However, assumptions need to be made if indirect taxes and in-kind benefits are to be allocated to individual households. These assumptions are detailed in the ABS publications (for example, 1996a:5977). As experience has been gained and priorities have changed, the ABS has changed the way it allocates some taxes and benefits. As new policies (such as the Higher Education Contribution Scheme) have been introduced, the allocation procedures have had to be revised to take account of them. One of more significant changes concerns the allocation to households of benefits for child care. In the 1993/94 survey, outlays on child care were allocated to households with children under twelve years according to household income and the probability that the household used child care. In previous surveys, outlays on child care were not separately identified but formed part of total indirect benefits in social security and welfare, which were then allocated to households that received social security cash payments. This revised procedure may have influenced the 1993/94 survey's recorded share of benefits received by families with children.

Two particular difficulties with the ABS data need to be addressed before the effect of the welfare state on particular types of household can be studied. First, differing proportions of taxes and government expenditures are allocated in the various surveys. For example, 54 per cent of government revenues, but 48 per cent of government expenditures, were allocated in the 1993/94 survey. Thus, more 
benefits are allocated than taxes, and average benefits exceed average taxes. As the ABS recognises, the difference between government benefits and taxes for a particular group of households has no particular significance. Moreover, this difference can fluctuate considerably depending on government fiscal policy and the state of the economy. To focus on the underlying trends, this article calculates the shares of benefits received and taxes paid by each of the relevant groups.

Second, the shares of benefits received and taxes paid by a group can be affected by changes in the numbers in each group (as a result of demographic factors) as well as by changes in government expenditure and taxation policies. To correct for this, it is necessary to adjust changes through time in the shares of benefits received and taxes paid by various groups in the light of changes in the numbers in these groups. For example, if the share of government expenditure on a particular group increased faster than might have been expected on the basis of growth in its numbers, then it is reasonable to argue that expenditure policy has changed in favour of that group. It needs to be remembered that these groups represent different persons in each of the surveys.

\section{References}

Angus, G. \& G. Hall (1996), Child Abuse and Neglect Australia 1994-95, Australian Institute of Health and Welfare, Canberra (Child Welfare Series No. 16).

Australian Bureau of Statistics (ABS) (1986), Voluntary Community Work During the Year ended October 1986, Sydney (Cat. No. 4403.1).

- (1987), The Effects of Government Benefits and Taxes on Household Income, 1984, Canberra (Cat. No. 6537.0).

— (1990), Disability and Handicap, Australia, 1988, Canberra (Cat. No. 4120.0).

- (1992), 1988-89 Household Expenditure Survey, Australia, The Effects of Government Benefits and Taxes on Houschold Incomc; (Cat. No. 6537.0), Canberra.

— (1993), Disability, Aging and Carers, Australia, 1993, Summary of Findings, Canberra (Cat. No. 4430.0 ).

—_(1994), Australian Social Trends, 1994, Canberra (Cat. No. 4102.0).

— (1995), 1995-96 Govemment Financial Estimates, Australia, Canberra (Cat. No. 5501.0).

- (1996a), 1993-94 Household Expenditure Survey, Australia, The Effects of Government Benefits and Taxes on Household Income, Canberra (Cat. No. 6537.0).

- (1996b), Voluntary Work, Australia, Canberra (Cat. No. 4441.0).

- (1996c), Year Book, Australia, Canberra (Cat. No. 1301.0).

Cox, E. (1995), A Truly Civil Society. 1995 Boyer Lectures, $\Lambda$ BC Books, Sydney.

Cox, J. (1994), 'National Savings and Fiscal Policy', Agenda l(1): 25-32. 


\section{James Cox}

Economic Planning Advisory Council (EPAC) (1988), Income Support Policy, Taxation and Incentives, AGPS, Canberra (Council Paper No. 35).

Gray, J. (1990), Introduction to B. de Jouvenal, The Ethics of Redistribution, Liberty Press, Indianapolis.

Green, D. (1996), From Welfare State to Civil Society: Towards Welfare that Works in New Zealand, New Zealand Business Roundtable, Wellington.

Maley, B. (1996), 'Crime, Violence and the Australian Family', pp. 21-47 in Home Repairs: Building Stronger Families to Resist Social Decay, Centre for Independent Studies, Sydney.

Murray, D. (1979), 'The Changing Incomes of the Aged in Australia', Australian Economic Papers 18: 81-8.

New South Wales Department of Consumer Affairs (1994), Annual Report for the Year Ended 30 June 1994, Sydney.

Putnam, R. (1993), Making Democracy Work: Civic Tradition in Modern Italy, Princeton University Press, Princeton.

(1996), 'The Strange Disappearance of Civic America', Policy 12(1): 3-15.

Rosen, S. (1996), 'Public Employment and the Welfare State in Sweden', Journal of Economic Literature 34: 729-40.

Tanzi, V. \& L. Schuknecht (1995), The Growth of Government and the Reform of the State in Industrial Countries, International Monetary Fund,Washington DC (IMF Working Paper, WP/95/130).

Tapper, A. (1996), 'State of the Family, Recent Research in Australia', pp. 51-65 in Home Repairs: Building Stronger Families to Resist Social Decay, Centre for Independent Studies, Sydney.

Thomson, D. (1991), Selfish Generations: The Ageing of New Zealand's Welfare State, Bridget Williams Books, Wellington.

World Bank (1994), Averting the Old Age Crisis: Policies to Protect the Old and Promote Growth, Oxford University Press, New York. 